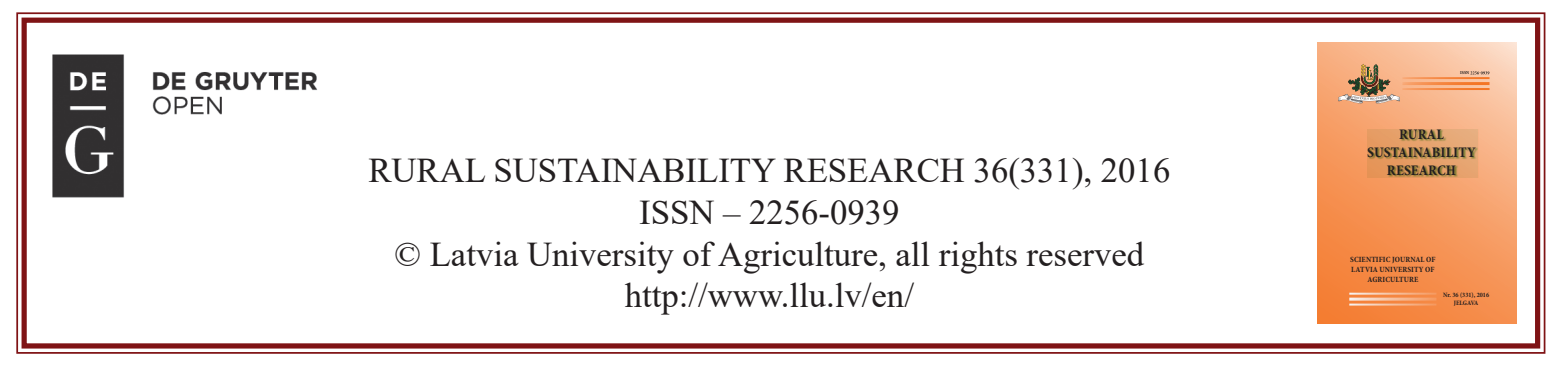

\title{
Fault Diagnosis of Low-Power Three-Phase Induction Motor
}

\author{
*Aleksejs Gedzurs \\ Latvia University of Agriculture, Faculty of Engineering, 5 Čakstes Blvd, Jelgava, LV -3004, Latvia
}

\begin{abstract}
An Induction motor reliability survey at an egg processing plant shows that almost $50 \%$ of the total motor failures are fan induction motors. Visual investigations of the faulty fan motors show that the main cause of the induction motor failure is air gap eccentricity. In this study, experimental tests are performed on a $1.1 \mathrm{~kW}$ three-phase induction motor to detect air gap eccentricity and overheating of the induction motor. Heating tests show that end shield housing temperature reaches $100^{\circ} \mathrm{C}$ with blocked air flow from the fan, which can reduce the lifespan of the bearing. Dimension measurements of the end shield housing show that the dimensions of both tested motors back-end shields are larger than ISO tolerance grade limit. It leads to a loose fit between the housing and bearing, causing air gap eccentricity. Also, both motor back end shield housing has an out-of-round condition leading to an unbalanced magnetic pull. To detect the air gap eccentricity caused by too loose of a fit between housing bore and bearing, current Park's vector approach is used. To measure three phase current, Hall Effect current transducers, a digital oscilloscope is used and Matlab software to process the measurement data. Results show that Park's vector approach can be used to detect the air gap eccentricity caused by too loose a fit between bearing and housing. Therefore, the Park's vector approach can be used to diagnose air gap eccentricity and analyse the type of the air gap eccentricity.
\end{abstract}

Keywords: induction motor, air gap eccentricity, Park's vector, stator current, stator winding heating, bearing housing.

\section{Introduction}

Induction motors (IM) are widely used in industry to drive pumps, lifts, cranes, hoists, lifts, compressors, fans, driving lathe machines, crushers, mills, conveyors, etc. During operations, several stresses on the motor can cause its failure. A reliability survey of IM at the egg processing plant 'Balticovo'(Iecava, Latvia) shows that annual failure rate is $2-3 \%$ of total IM number (Gedzurs, 2016). However, almost 50\% (123 failures during last 5 years) of total IM failures are fan IM. Fan driving motors are $1.1 \mathrm{~kW}$ three phase induction motors located in hen houses. Visual diagnosis of the faulty fan induction motors showed a sigh of stator/rotor rub. Rub between stator and rotor is caused by air gap eccentricity resulting in serious damage to the stator and rotor (Cardoso \& Saraiva, 1993).

There are many causes to air gap eccentricity improper mounting of IM and tensioning of drive belts, out-of-roundness of rotor or stator, bearing faults, bent shaft, etc. Air gap eccentricity also leads to increased vibrations, coil movement, which leads to accelerated insulation degradation. It is important to indicate the air gap eccentricity before it causes damage to induction motor parts. There are several methods available to detect air gap eccentricity, but current and vibration are commonly used. Vibration sensors are expensive and vibration measurement acquisition requires a significant investment (Huang, 2005).

There are three current monitoring methods: current Park's vector (a space phasor), zero-sequence and negative-sequence, current spectral analysis. In the study (Cardoso, \& Saraiva, 1993) Park's vector approach is successfully used to detect air gap eccentricity of an induction motor. Fast Fourier transformation (FFT) is often used for motor current signature analysis techniques (Pons-Llinares et al., 2012). To perform the FFT technique only one phase current measurement is needed, while Park's vector approach requires all three phases. However, FFT is not effective at light loads conditions, but with Park's

\footnotetext{
* Corresponding Author's email: aleksejs.gedzurs@1lu.lv
} 
vector approach, it is easy to diagnose the fault of the induction motor (Mehala, 2010).

The objective of the study is to investigate and diagnose the air gap eccentricity presence and operation condition impact on the fan driving induction motor parts.

\section{Materials and Methods}

For this study, two three-phase induction motors are used: ABB M2AA90S-4; 220-240/380-420 V; 4.6/2.66A; IP55; insulation class - $\mathrm{F}, \mathrm{m}=13 \mathrm{~kg}$; $\mathrm{P}=$ $1.1 \mathrm{~kW} ; \mathrm{n}=1410 \mathrm{~min}^{-1} ; \mathrm{s}=0.06$; efficiency class - IE1 $(75 \%)$ high efficiency motor; $\cos \varphi=0.81$, drive side bearing -6205 (outside diameter $\mathrm{D}=52 \mathrm{~mm}$ ), back side $-6204(\mathrm{D}=47 \mathrm{~mm})$. These motors are used at the egg processing plant 'Balticovo' in Iecava, Latvia and are driving fans in the hen houses. Operation conditions in the hen houses are as follow: dust from grain feeding system, aggressive gasses and belt driving system. These conditions lead to increased heating of the motor due to a dust layer on the motor surface, increased bearing wear due to higher temperature and belt drive system, contamination (mix grease and dust) on the stator winding and bearing as shown in Figure 1 (Gedzurs, 2016). One of the motors (Motor A) is rewinded after a failure, the second motor (Motor B) is still operational, but has a sign of a stator/rotor rub after a long operation time.

Grease presence outside the bearing and charred contaminations are a sign of overheating of the bearings. As it is shown in Figure 1b, the overheating reason is the layer of dust that blocks the air flow from the fan, thus decreasing heat dissipation from the motor. To evaluate the impact of blocked ventilation on overheating of the induction motor, an experiment is performed. For this experiment, Motor $\mathrm{A}$ is used. The motor is operated at rated load and the fan was taken off to imitate the blocked ventilation condition (natural ventilation). To measure the temperature of the IM parts, K-type thermocouples BK-50 (air probe - SE000) are installed in the stator windings and back end shield housing (Figure 2). For data acquisition a Pico-Log TC-08 logger with built in cold junction compensation is used (the accuracy of temperature reading $- \pm 0.2 \%$ of measurement reading plus $\pm 0.5^{\circ} \mathrm{C}$ ).

During visual investigation of Motor A and Motor $\mathrm{B}$, the end shields came off the bearings easily,

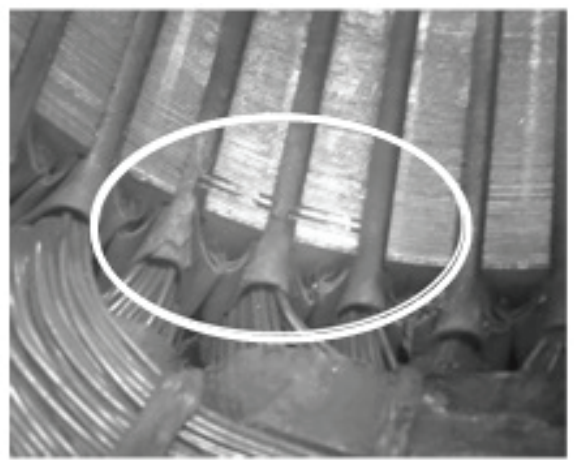

a)

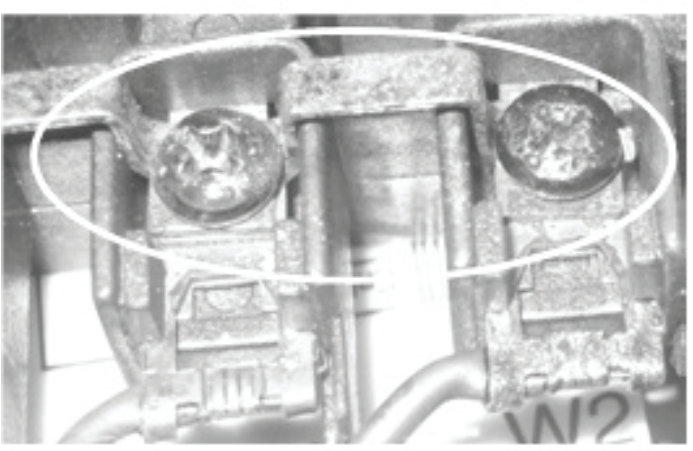

c)

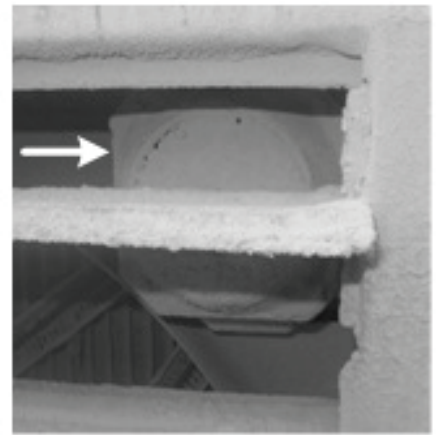

b)

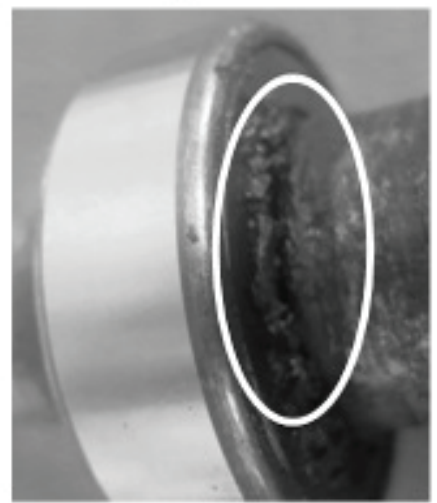

d)

Figure 1. Impact of operation conditions on induction motor:

$\mathrm{a}$ - result of a rub between stator and rotor (Motor B); b - induction motor covered by dust during operation; $\mathrm{c}$ - corrosion of induction motor connection leads; $\mathrm{d}$ - bearing contamination. 


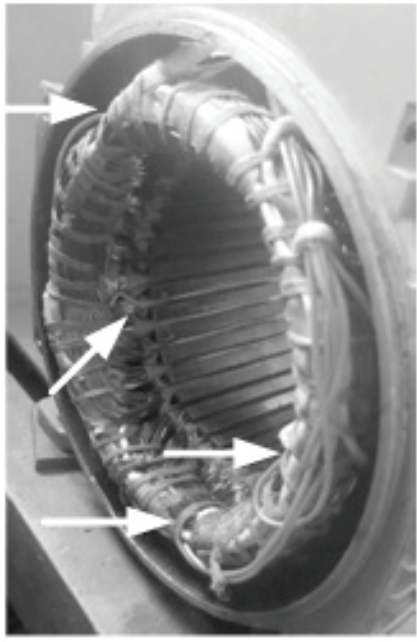

a)

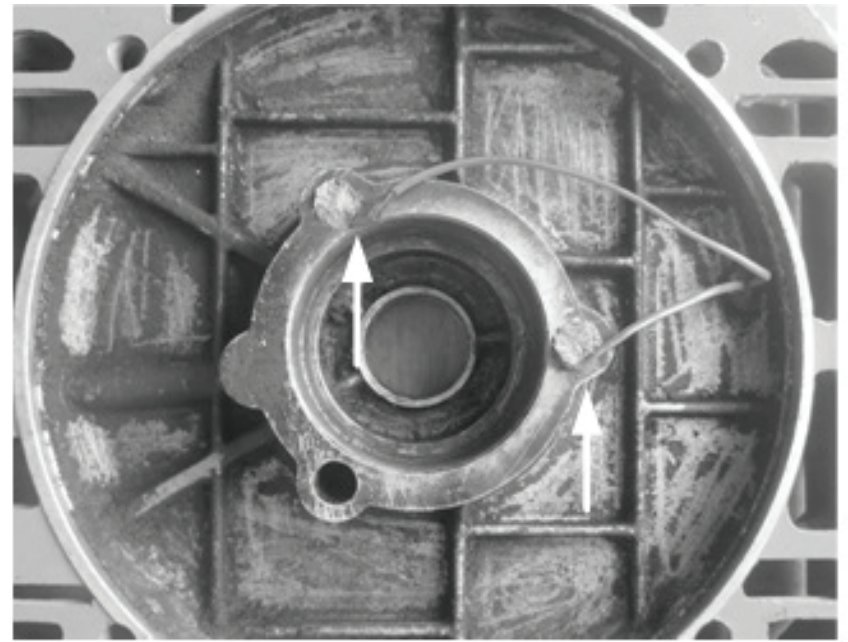

b)

Figure 2. Location of the thermocouples in the induction motor: $\mathrm{a}$-thermocouples in the stator windings; $\mathrm{b}$ - thermocouples in the back end shield housing.

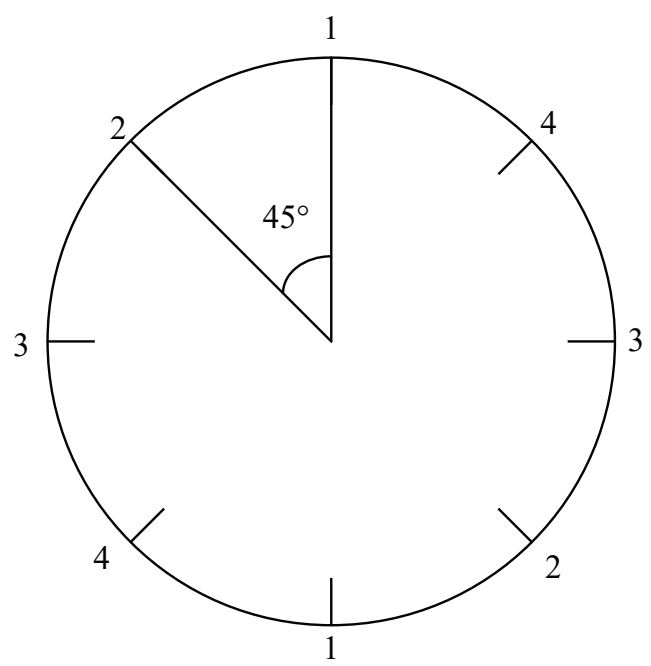

Figure 3. Measurements' points of housing dimensions.

especially the back end shield (fan side). This means that there is too loose of a fit between the end shield housing and bearing. A loose fit allows the bearing ring to slip or creep in the housing. Also, the bearing looseness leads to an air gap eccentricity. Therefore, the dimensions of both end shield housings for Motor A and Motor B are measured at four points as shown in Figure 3 (Industrial Bearing Maintenance Manual, 2009).

Results of bearing wear, over-tensioning of the drive belt and a loose fit between housing and bearing are leading to an air gap eccentricity. There are two types of air gap eccentricity - static and dynamic eccentricity. Static eccentricity occurs when the centreline of the rotor is at constant offset from the centreline of the stator, for dynamic eccentricity the offset is variable. In this study the effect of the housing dimensions on the air gap eccentricity is investigated. For this investigation, Motor A is also used. First, the motor is tested with end shields from motor $\mathrm{A}$ and then the end shields are replaced with shields from Motor B. Brand new bearings are used for these experiments. The motor is operated with no load conditions to nullify the eccentricity caused by bearing wear and drive coupling. To detect air gap eccentricity, the Park's vector approach is used. Connection of three phase induction motors usually does not require the neutral. Therefore, the current has no zero-sequence component. A two-dimensional representation of the phase stator current can be used for three phase IM operation conditions. Knowing the instantaneous three phase current values the Park's 
vector components can be calculated (Cardoso \& Saraiva,1993):

$$
\begin{aligned}
& i_{d}=\sqrt{\frac{2}{3}} \cdot i_{a}-\sqrt{\frac{1}{6}} \cdot i_{b}-\sqrt{\frac{1}{6}} \cdot i_{c} \\
& i_{q}=\sqrt{\frac{1}{2}} \cdot i_{b}-\sqrt{\frac{1}{2}} \cdot i_{c}
\end{aligned}
$$

where $i_{a}, i_{b}, i_{c}-$ instantaneous values of three phase currents, A;

$i_{d}, i_{q}-$ Park's vector components, A.

Under ideal conditions, the Park's vector components are:

$$
\begin{aligned}
& i_{d}=\frac{\sqrt{6}}{2} \cdot I_{m} \cdot \sin (\omega \cdot t) \\
& i_{q}=\frac{\sqrt{6}}{2} \cdot I_{m} \cdot \sin \left(\omega \cdot t-\frac{\pi}{2}\right)
\end{aligned}
$$

where $I_{m}-$ maximum value of stator phase current, A;

$\omega-$ angular frequency, $\operatorname{rad} \cdot \mathrm{s}^{-1}$;

$\mathrm{t}$ - time, $\mathrm{s}$.

and will represent a perfect circle in $\mathrm{XY}$ graph. Different faults of an induction motor and power supply unbalances will create a unique pattern in the Park's vector figure. For example, under stator winding inter-turn short-circuit faults the Park's vectors pattern becomes elliptic, under broken rotor bars faults - patterns average thickness increases (Cardoso, Cruz, \& Fonseca, 1999; Estima, Freire \& Cardoso, 2013).

To measure three phase current, three LEM LA 100-TP Hall effect current transducers (accuracy $\pm 0.7 \%$ ) are used for both heating and air gap eccentricity experimental investigations. Sensor's output signal is measured by two channel Tektronix TBS 1052B-EDU digital oscilloscope and measured data is saved on a USB flash. After that, measuring data is processed in Matlab. A time window of 40 $\mathrm{ms}$ (period of the rotor synchronous speed) is used to measure the current. The number of samples per channel is 2000 .

\section{Results and Discussion}

Experimental test results of the IM heating, under rated load and blocked ventilation condition are shown in Figure 4. Heating test results (Gedzurs $\&$ Sniders, 2015) of the same motor under forced ventilation condition is also presented in Figure 4. The temperature rise under blocked air flow conditions is $\Delta \theta_{1}=109{ }^{\circ} \mathrm{C}$, more than two times higher than temperature rise $\Delta \theta_{2}=47^{\circ} \mathrm{C}$ under forced ventilation condition. Results show, that the stator end windings temperature rises to $140^{\circ} \mathrm{C}$ under blocked

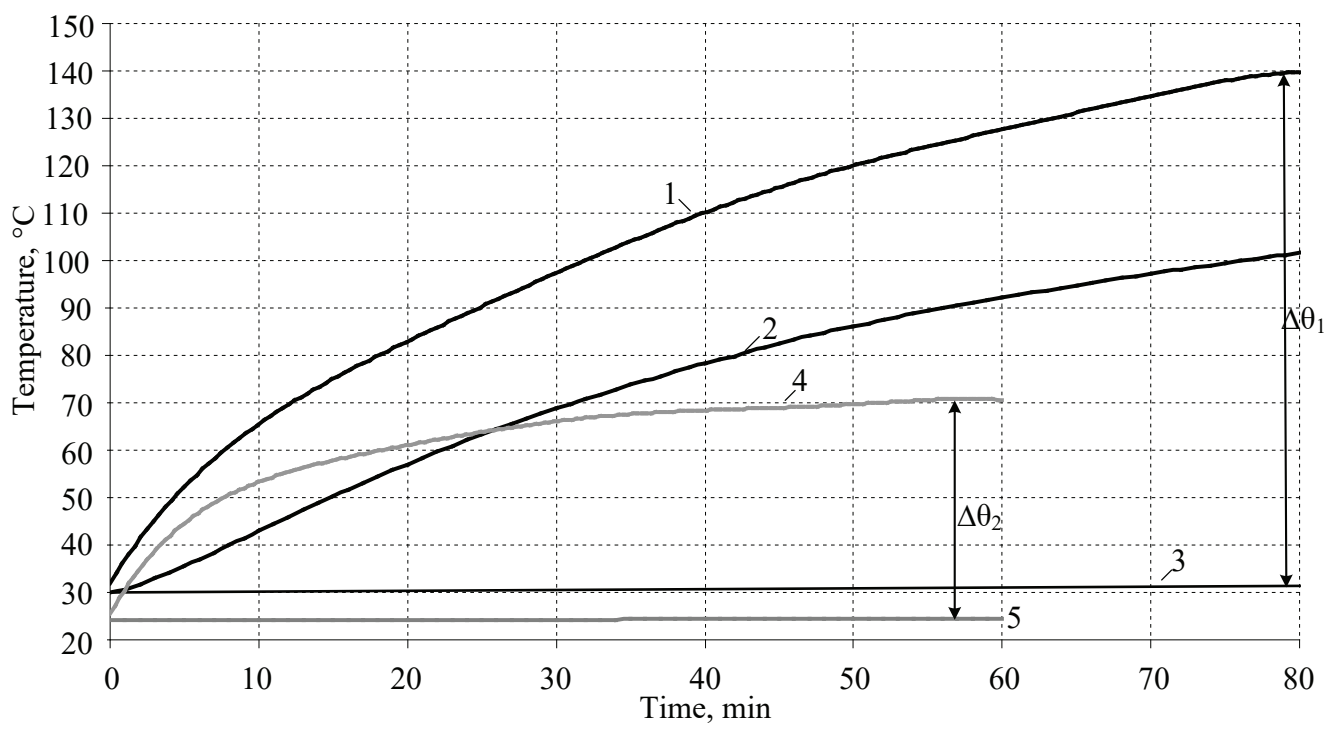

Figure 4. Experimental results of heating process of Motor A under forced and natural ventilation conditions: 1 - temperature of stator end windings under blocked air flow condition; 2 - temperature of back end shield housing under blocked air flow condition; 3 - ambient temperature during experiment under blocked air flow; 4 - temperature of stator end windings under forced ventilation condition; 5 - ambient temperature during experiment under forced ventilation condition. 


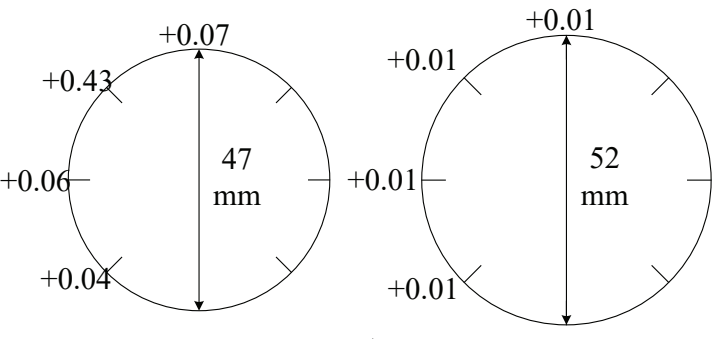

a)

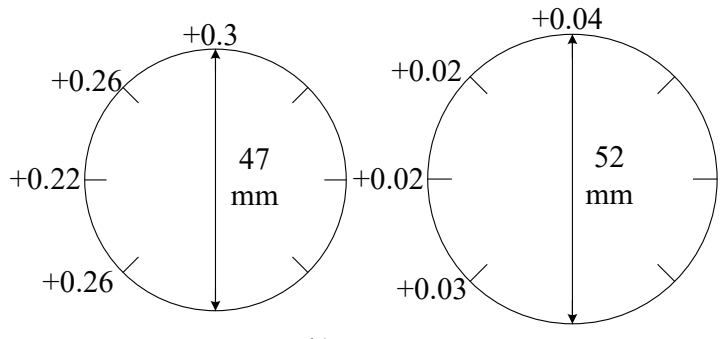

b)

Figure 5. Measured dimensions of motors end shields: $\mathrm{a}-$ end shields of Motor A; $\mathrm{b}$ - end shields of Motor B.

air flow condition. The tested motor's stator windings have a $\mathrm{F}$ insulation class and can withstand $140{ }^{\circ} \mathrm{C}$ temperature.

According to bearing manufacturer SKF recommendations, the housing temperature should not be more than $82{ }^{\circ} \mathrm{C}$. The bearing outer ring can be up to $11^{\circ} \mathrm{C}$ higher than the housing. As a rule of thumb, grease life is halved for every $10^{\circ} \mathrm{C}$. Tests show (Figure 4), that the housing temperature reaches 101 ${ }^{\circ} \mathrm{C}$. Therefore, temperature of the bearing cab higher than $101{ }^{\circ} \mathrm{C}$, which leads to decreased lifespan of the bearing, as the bearing is not designed for operation under high temperature.

For rolling bearing applications, a limited number of ISO tolerance grades are used. The selection of the tolerance grade mainly depends on the operation conditions of the application. Generally H7 gate is used for electric motors. According to SKF handbook for bearings and seals (Rolling bearing and seals in electric motors and generators, 2013), a tighter fit should be used for motors with an aluminium housing, e.g. J7 instead of H7. The tested motor's housing is made from aluminium; therefore, the J7 tolerance limits are used to evaluate Motor A and Motor B housing fits. Housing dimensions are measured as described in bearing maintance manual (Industrial Bearing Maintenance Manual, 2009). The measurement results are shown in Figure 5. The average measurement of all four points $\left(0^{\circ}, 45^{\circ}\right.$, $90^{\circ}, 135^{\circ}$ ) should be calculated and verified, if it is between the $\mathrm{J} 7$ grade limits $-0.012 \mathrm{~mm}$ and 0.018 $\mathrm{mm}$ for front end shield housing, $-0.011 \mathrm{~mm}$ and $0.014 \mathrm{~mm}$ for back end shield. Housing dimensions are measured using a bore gauge with a resolution of $0.01 \mathrm{~mm}$. The mean value of measurements of all four points is presented in Table 1 .

The housing dimensions of Motor A front end shield are within the tolerance limits, but the average diameter of back end shield housing is higher than the maximum tolerance limit (Table 1). For Motor $\mathrm{B}$, dimensions of both end shield housings are higher than the limit. Diameter of the back end shield housing diameter for Motor B is $0.26 \mathrm{~mm}$ longer than the bearing outside diameter. Such a large difference will create significant air gap eccentricity and can lead to rub between stator and rotor.

To check the roundness of the housing, each individual measurement at angle $0^{\circ}, 45^{\circ}, 90^{\circ}$ and $135^{\circ}$ needs to be compared. If any measurement is larger or smaller than one half the $\mathrm{J} 7$ tolerance limit an out-of-

\section{Measurement results of housing bores}

\begin{tabular}{|c|c|c|c|c|c|c|c|c|}
\hline & & \multicolumn{4}{|c|}{ Measurement results, mm } & \multirow[t]{2}{*}{ Averagemm } & \multicolumn{2}{|c|}{$\begin{array}{l}\text { J7 housing } \\
\text { tolerance limit, } \mathrm{mm}\end{array}$} \\
\hline \multicolumn{2}{|c|}{ Measurement points } & $0^{\circ}$ & $45^{\circ}$ & $90^{\circ}$ & $135^{\circ}$ & & $\min$ & $\max$ \\
\hline \multirow{2}{*}{ Motor A } & front & $\begin{array}{c}0.01 \\
\pm 0.01\end{array}$ & $\begin{array}{c}0.01 \\
\pm 0.01\end{array}$ & $\begin{array}{c}0.01 \\
\pm 0.01\end{array}$ & $\begin{array}{c}0.01 \\
\pm 0.01\end{array}$ & 0.01 & -0.012 & 0.018 \\
\hline & back & $\begin{array}{c}0.07 \\
\pm 0.01\end{array}$ & $\begin{array}{c}0.04 \\
\pm 0.01\end{array}$ & $\begin{array}{c}0.06 \\
\pm 0.01\end{array}$ & $\begin{array}{c}0.04 \\
\pm 0.01\end{array}$ & 0.05 & -0.011 & 0.014 \\
\hline \multirow{2}{*}{ Motor B } & front & $\begin{array}{c}0.04 \\
\pm 0.01\end{array}$ & $\begin{array}{c}0.02 \\
\pm 0.01\end{array}$ & $\begin{array}{c}0.02 \\
\pm 0.01\end{array}$ & $\begin{array}{c}0.03 \\
\pm 0.01\end{array}$ & 0.03 & -0.012 & 0.018 \\
\hline & back & $\begin{array}{c}0.30 \\
\pm 0.01\end{array}$ & $\begin{array}{c}0.26 \\
\pm 0.01\end{array}$ & $\begin{array}{c}0.22 \\
\pm 0.01\end{array}$ & $\begin{array}{c}0.26 \\
\pm 0.01\end{array}$ & 0.26 & -0.011 & 0.014 \\
\hline
\end{tabular}


Comparison of measurements of housing bores

\begin{tabular}{|c|c|c|c|c|c|c|c|}
\hline \multicolumn{2}{|c|}{} & \multicolumn{5}{|c|}{ Differences of housing bore measurements, $\mathrm{mm}$} \\
\hline \multicolumn{2}{|c|}{ Measurement points } & $0^{\circ}-45^{\circ}$ & $0^{\circ}-90^{\circ}$ & $0^{\circ}-135^{\circ}$ & $45^{\circ}-90^{\circ}$ & $45^{\circ}-135^{\circ}$ & $90^{\circ}-135^{\circ}$ \\
\hline \multirow{2}{*}{ Motor A } & front & 0.00 & 0.00 & 0.00 & 0.00 & 0.00 & 0.00 \\
\cline { 2 - 8 } & back & 0.03 & 0.01 & 0.03 & 0.02 & 0.0 & 0.02 \\
\hline \multirow{2}{*}{ Motor B } & front & 0.02 & 0.02 & 0.00 & 0.00 & 0.01 & 0.01 \\
\cline { 2 - 8 } & back & 0.04 & 0.08 & 0.04 & 0.04 & 0.04 & 0.00 \\
\hline
\end{tabular}

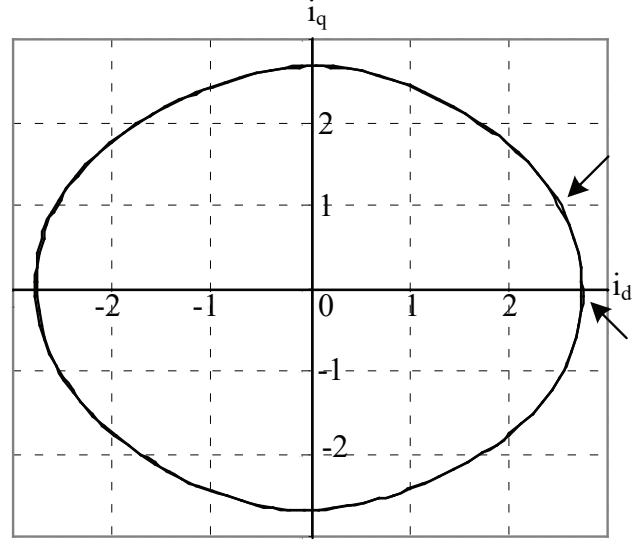

a)

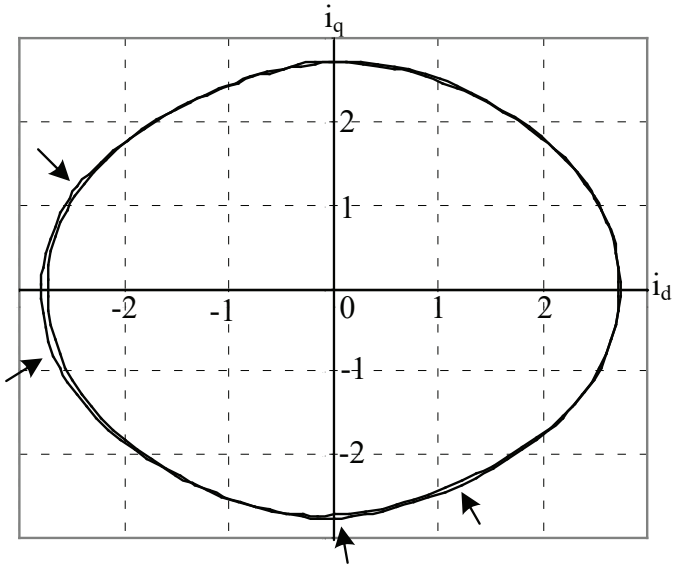

b)

Figure 6. Measured dimensions of motors end shields: $\mathrm{a}$ - end shields of Motor A; b - end shields of Motor B.

round condition exists $(0.015 \mathrm{~mm}$ for front end shield housing and $0.0125 \mathrm{~mm}$ for back end shield housing) (Industrial Bearing Maintenance Manual, 2009). The results show that both Motor A and B back end shield housings have an out-of-round condition. This condition will cause unbalanced magnetic pull.

The current Park's vector representation for Motor A is shown in Figure 6 with original end shields and end shields from Motor B. Since Motor's B back end shield housing is $0.26 \mathrm{~mm}$ longer than bearing outside diameter and Motor's A shields housing is $0.05 \mathrm{~mm}$, there should be a significant difference in air gap eccentricity and it's impact on stator current.

As seen in Figure 6, the difference between Park's vector patterns can be seen. The greater is the air gap eccentricity, the greater is the area between the patterns. A zoom of the Park's vector modulus $i_{\mathrm{q}-\mathrm{d}}$ is presented in Figure 7. With air gap eccentricity 0.053 $\mathrm{mm}$ the maximum difference of $0.02 \mathrm{~A}$ between, while $0.261 \mathrm{~mm}-0.057 \mathrm{~A}$. One can conclude that a strong correlation may exist between the level of loose fit and the area between the Park's vector patterns. The experimental results show that Park's vector can be used to detect air gap eccentricity caused by too loose of a fit between the bearing and end shield housing.

The experimental study shows if the motor is covered by a layer of dust, overheating of bearings and other parts occur. These conditions can significantly reduce bearing's lifespan and amplify the air gap eccentricity, if it is present. The out-of-round condition of the end shield housing is caused by asymmetrical force on the shaft due to the nature of the belt drive. To increase operation time of the induction motors under these conditions, bearings with higher temperature limits should be used, correct tension of the drive belt ensured and periodic maintenance performed.

The out-of-round condition of the housing causes a dynamic air gap eccentricity. In a study (Cardoso \& Saraiva,1993) Park's vector pattern is presented for static air gap eccentricity. The patterns do not cross each other under static eccentricity, like they do under dynamic eccentricity (Figure 7). Therefore, Park's vector approach can be used not only to detect the air gap eccentricity, but also to analyse the type of air gap eccentricity. 


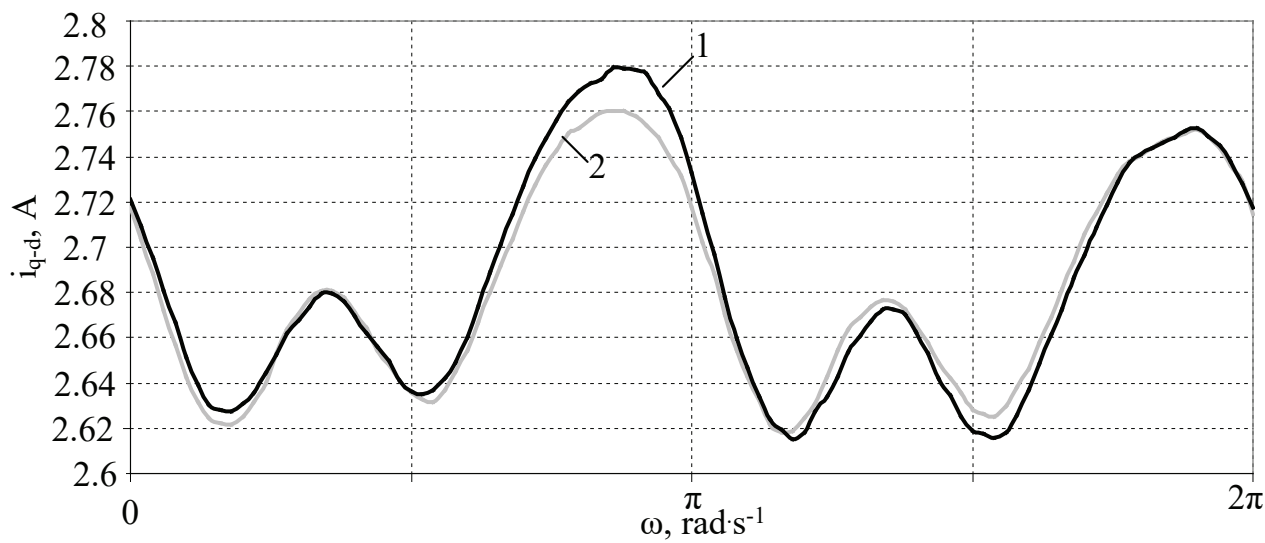

a)

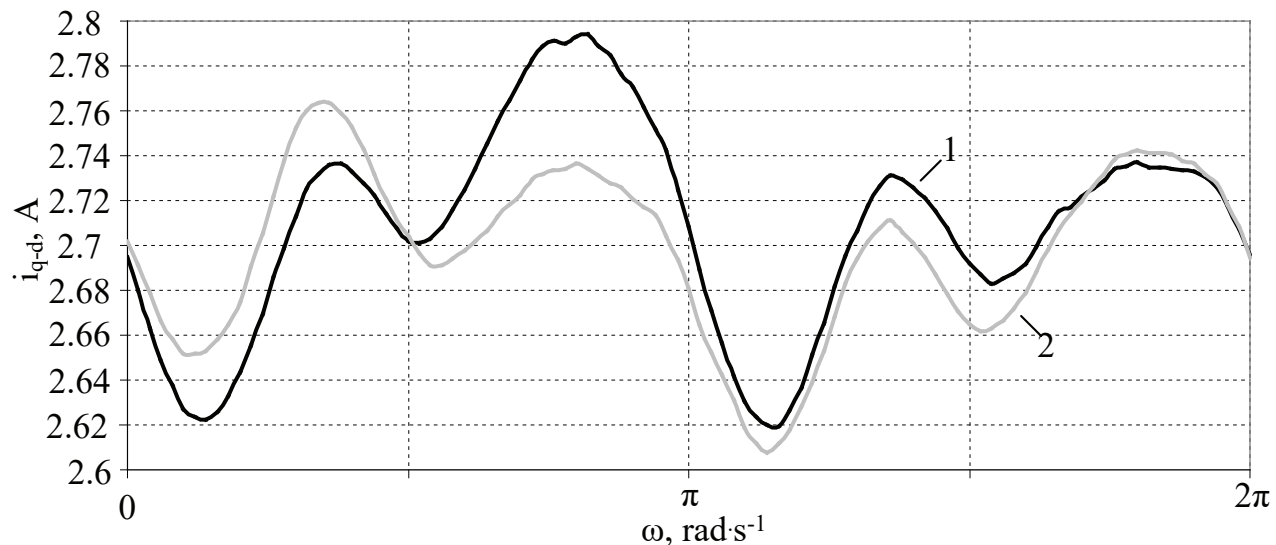

b)

Figure 7. Zoom of the current Park's vector modulus as a function of its angular position: $\mathrm{a}$ - with end shields of Motor A; b - with end shields of Motor B; 1 - Park's vector modulus curve in time period $0-20 \mathrm{~ms} ; 2$ - Park's vector modulus curve in time period $21-40 \mathrm{~ms}$.

\section{Conclusions}

1. The results of the heating tests under rated load and no forced ventilation condition show that temperature of the back end shield housing reaches $101^{\circ} \mathrm{C}$. Taking into account, that the temperature of the bearing's outer ring can be higher than the temperature of the housing, bearing is operating at higher temperature than it is recommended. Presence of contamination and overheating can result in significant decrease of the bearing lifespan.

2. Dimensions of Motor's A back end shield and Motor's B both end shield housings are higher than the required limit of the ISO tolerance grade. Therefore, too loose fit between bearing and housing leads to air gap eccentricity. Measurements show that both motor's back end shield housings have out-of-round condition which leads to a dynamic air gap eccentricity.

3. Experimental investigations show that Park's vector approach is able to detect air gap eccentricity. Air gap eccentricity of $0.05 \mathrm{~mm}$ leads to a maximum $0.02 \mathrm{~A}$ difference between Park's vector patterns, but $0.26 \mathrm{~mm}$ air gap eccentricity -0.057 A. A strong correlation may exist between Park's vector pattern split area and airgap eccentricity level. Also, Park's vector can help to analyse the type of the air gap eccentricity.

\section{References}

1. Cardoso, A.J.M. \& Saraiva, E.S. (1993). Computer-aided detection of airgap eccentricity in operating three-phase induction motor by Park's vector approach. IEEE Transactions on Industry Applications. 29(5), 897-901. DOI: 10.1109/28.245712.

2. Cardoso, A.J.M., Cruz, S.M.A. \& Fonseca, D.S.B. (1999). Inter-turn stator winding fault diagnosis in three-phase induction motors by Park's vector approach. IEEE Transactions on Energy Conversion. 14(3), 595-598. DOI: 10.1109/60.790920. 
3. Estima, J.O., Freire, N.M.A., \& Cardoso, A.J.M. (2013). Recent advances in fault diagnosis by Park's vector. In 2013 IEEE Workshop on Electrical Machines Design, Control and Diagnosis, 12-14 March 2013 (pp. 279-288). Pierre and Marie Curie University, Paris, France: IEEE Industrial Electronics Society.

4. Gedzurs, A., \& Sniders A. (2015). Experimental Research and Simulation of Induction Motor Stator Winding Non-Stationary Heating. American Journal of Energy and Power Engineering. 2(4), 44-50.

5. Gedzurs, A. (2016). Operation reliability of induction motors at egg processing plant 'Balticovo'. Agronomy Research. 14(S1), 11611168.

6. Huang, X. (2005). Diagnostics of air gap eccentricity in closed-loop drive-connected induction motor. Dissertation, School of Electrical and Computer Engineering, Georgia Institute of Technology, Atlanta, USA.
7. Industrial Bearing Maintenance Manual. (2009). Canada: The Timken Group.

8. Mehala, N. (2010). Condition monitoring and fault diagnosis of induction motor using motor current signature analysis. Dissertation, Electrical Engineering department, National Institure of technology, Kurukshetra, India.

9. Pons-Llinares, J., Climente-Alarcon, V., Vedreno-Santos, F., Antonino-Daviu, J. \& Riera- (2012). Electric machines diagnGuasp, M. Electric machines diagnosis techniques via transient current analysis. In IECON 2012 - $38^{\text {th }}$ Annual Conference on IEEE Industrial Electronics Society, 25-28 October 2012 (pp. 59-64). Melbourne, Victoria, Australia: Australian Library and Information Association.

10. Rolling bearing and seals in electric motors and generators. (2013). SKF Group. 